九州大学学術情報リポジトリ

Kyushu University Institutional Repository

\title{
NOTES AND DESCRIPTIONS OF THE CARABIDAE FROM MT. HIKO AND ITS VICINITY (Coleoptera)
}

Habu, Akinobu

https://doi.org/10.5109/2345

出版情報: ESAKIA. 2, pp.3-6，1960-02-20. Hikosan biological laboratory，Faculty of Agriculture, Kyushu University バージョン：

権利関係 : 
ESAKIA No. 2

February 20, 1960

\title{
NOTES AND DESCRIPTIONS OF THE CARABIDAE FROM MT. HIKO AND ITS VICINITY*
}

\author{
(Coleoptera)
}

\section{BY}

\section{Akinobu Habu}

This small paper is based on the specimens from Mt. Hiko and its vicinity in Kyushu, rendered under the guidance of the late Professor T. Esaki, and Professor K. Yasumatsu, the present head of the Hikosan Biological Laboratory. I wish to express my cordial appreciation to these excellent entomologists for their kind encouragement to my taxonomical work, to Mr. E. B. Britton of the British Museum for his kind aid in Bates' type specimens, and to Mr. Y. Takakura for his kind aid in mater ial.

\section{Pterostichus (s. str.) pachinus Bates}

Pterostichus pachinus Bates (1883) Trans. Ent. Soc. London : 245.

Pterostichus (s. str.) pachinus Habu (1955) Bull. Nat. Inst. Agr. Sci. [c] no. 5 : 150-152, figs. 4,6 .

Remarks. I had a chance to see one of Bates' type specimens from Junsai, Hokkaido, This specimen is somewhat different from a series of the specimens from Mt. Hiko and Mt. Ichifusa, Kumamoto Prefecture, in the following points : the neck-constriction of the head is moderate on its lateral sides, but very faint on the dorsal side in the specimen from Hokkaido, while it is moderately constricted both on the dorsal and lateral sides in the specimens from Kyushu; the prothorax is wider, about oneand-one-third times as wide as long in the former, but a little narrower, one-andone-fifth to -one-fourth times as wide as long in the latter; the aedeagus is a little more curving ventrally before the apex in the former.

However, I can not regard the above characteristics as of specific or subspecific value unless further material, especially specimens from Honshu, is available.

In the description given by Habu (1955) I must correct the following point :p. 151, line 9, "so breit wie lang" must read "so lang wie breit."

* Contribution Ser. 2, No. 5, Hikosan Biological Laboratory, Kyushu University, Hikosan. 
Fukuchina gen. nov.

Genotype: Fukuchina sanadai sp. nov.

Description. Head rather wide; dorsal side glabrous; temporae very short; eyes large and convex; frons with two pairs of supraorbital setae; clypeus with a pair of setae; labrum transverse, with normal six setae; mandibles short; antennae somewhat stout, basal three segments rather sparsely 'pubescent, segment 4 and following segments densely pubescent ; apical segment of palpi fusiform; mentum without tooth, epilobes extending beyond lateral lobes as a sharp tooth, border between epilobes and lateral lobes rather distinct.

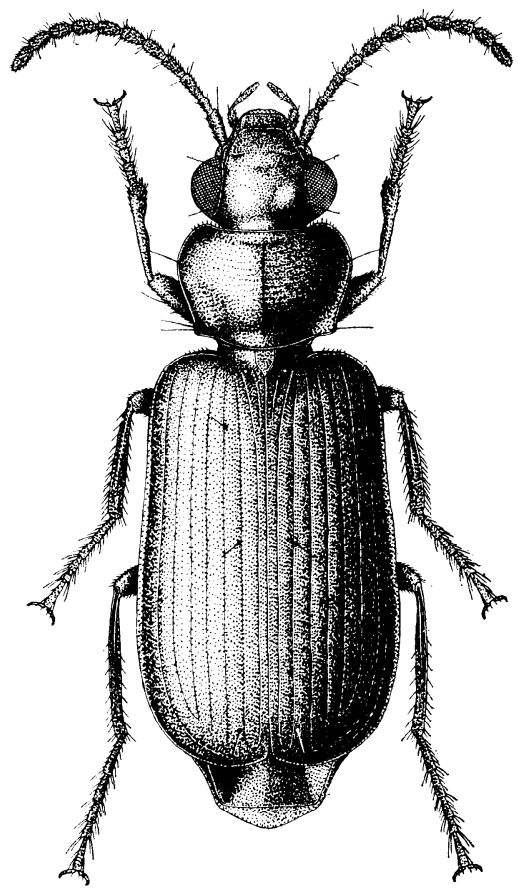

Fig. 1. Fukuchina sanadai sp. nov. (우, holotype)

Prothorax transverse ; dorsal side glabrous; base emarginate at lateral parts, so obtusely protrudent at median part; lateral sides with two pairs of setae.

Elytra elongate ; apex (Fig. 2, A) widely rounded, not truncate nor emarginate ; sparsely finely ciliate only along lateral and apical margins; basal border incomplete; basal pore present; interval 3 with some pores.

Legs moderate in length ; tarsal segment 4 not bilobed; claws (Fig. 2, B) long, not pectinate.

Remarks. The form of the prothorax reminds of the species of Lebia of the tribe Lebiini, but simple, not pectinate claws of the tarsi suggest that this genus may be allied to Apristus, but Fukuchina is easily distinguishable from it by the large size, the mentum without tooth, the transverse prothorax obtusely protrudent at the base.

In 1949, Jeannel* established one new family Lionychidae for Lionychus Wissmann, Apristus Chaudoir, Microdaccus Schaum, Pseudotrechus Rosenhauer, and Eremolestes Maindron. Fukuchina should be included into this group.

This genus falls into Trichis Klug in the key given by Jedlička, $\uparrow$ who placed this genus in the subtribe Lebii of the Lebiini, in "Klauen einfach; Seitenrand des Halsschildes vorne und die Schultern mit langen gelben Borsten; Flügeldecken .... an deu Seiten parallel,...." Though I have no knowledge about this genus, in Trichis, after

* Col. Carab. Rég. Malgache, pt. 3 : 1003 (1949).

† Versuch einer Monographie der pal. Carabiden-Gattungen mit abgestutzten Flügeldecken (Truncatipennen) mit Berücksichtigung der indischen Fauna: 16 (1941). 
Lacordaire, * the mentum is "trilobe", the head is "non rétrécie en un col postérieurement", the prothorax is not transverse but "assezallongé," and the elytra are "echancrées a leur extrémité."

Fukuchina sanadai sp. nov.

\section{"Kuro-nagabane-gomimushi"}

Description. Length $6.8 \mathrm{~mm}$. (from apex of mandibles to apex of elytra) or $7.4 \mathrm{~mm}$. (from apex of mandibles to apex of abdomen).

Black, head and prothorax shiny, but elytra somewhat mat; head with a pair of obscure reddish patches on frons between eyes ; apical part of clypeus, labrum, mandibles and palpi dark reddish brown, antennae and legs slightly reddish, but coxae, trochanters and basal part of femora brown; ventral side dark reddish brown.

Head gently convex; dorsal side very minutely sparsely punctate ; microsculpture faint, isodiametric ; neck fairly constricted at lateral sides, faintly at dorsal side;
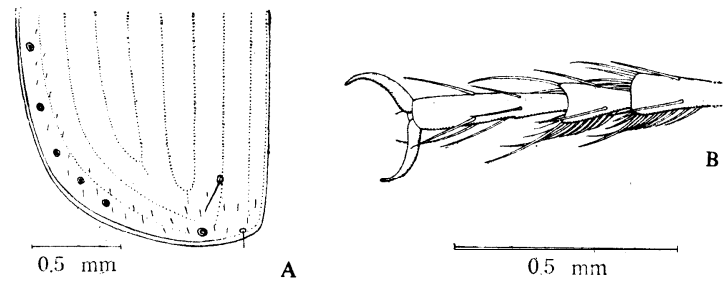

Fig. 2. Fukuchina sanadai sp. nov,

A. Apical part of the left elytron.

B. Segments 3 to 5 of the right hind tar\&.

posterior supraorbital setae inserted near eyes, a little before level of posterior margin of eyes; frons with a faint depression at middle between anterior supraorbital setae; frontal furrows very shallow, faintly extending forwards onto clypeus as far as clypeal setae; clypeus slightly convex at baso-median part, almost straight at apical margin ; mandibles with sparse fine short cilia on outer groove; antennae reaching shoulders, segment 3 a little longer than segment 4 or 5 ; palpi sparsely finely ciliate, apical segment of maxillary palpi slightly longer than penultimate segment.

Prothorax gently convex, widest at apical one-third; one-and-one-sixth times as wide as head, less than one-and-one-half times as wide as long $\dagger$; dorsal side transversely rugose, finely sparsely punctate ; microsculpture rather distinct, but fairly strong in basal foveae; apical margin widely emarginate, densely ciliate, but rather sparsely pubescent on and near apical angles, completely bordered ; apical angles somewhat protrudent, widely rounded ; basal margin completely bordered, lateral sinuations rather weak ; basal angles obtuse ; lateral margins moderately rounded, but faintly emarginate just before basal angles; anterior marginal setae at widest part,

* Gen. Col. I: 111-112 (1854).

+ The length of the prothorax was represented by the length between the middle of the apical margin and that of the basal margin. 
posterior marginal setae * on basal angles ; lateral channels narrow ; median line fine, reaching neither extremity; anterior transverse impression faint, posterior transverse impression rather deep; basal foveae short but rather wide, deep along lateral parts of basal margin.

Wings developed. Elytra elongately quadrate, gently convex, widest at about threefourths ; one-and-one-half times as wide as prothorax, three-and-three-fifths times as long $\dagger$ as prothorax, less than one-and-two-thirds times as long as wide; sparsely punctate; microsculpture evident, isodiametric ; lateral margin rounding shoulder and ending at base of stria 3 ; shoulder distinct though rounded, pubescent ; lateral margin gently dilated up to widest part, faintly emarginate before middle, thence fairly rounding as far as apex, inner apical angle obtuse, widely rounded ; striae shallow and almost complete as far as apical part, but abbreviate near base, stria 7 almost reaching interval 3 at apex; scutellary striole faint though moderately long ; intervals weakly convex, interval 3 with three pores, each pore before one-fifth, before middle and before apex, first pore adjoining to stria 3, second and third adjoining to stria 2; marginal series of pores not interrupted, about eighteen in number.

Fore tibiae pubescent at apical one-third portion; tarsi sparsely setose on dorsal side, tarsal segment 5 with two or three long setae at ventral part on each side.

Ventral side impunctate, but ventral abdominal segments with ciliate minute punctures, prosternum pubescent at middle ; metaepisterna nearly one-and-three-fourths times as long as wide; ventral abdominal segments 3 to 5 with a pair of long setae near middle, segment 6 with two pairs of marginal setae in 으, but inner pair shorter and finer than outer pair, apical margin rounded.

Type locality. Fukuoka Prefecture, North Kyushu, Japan.

Type specimen. Holotype: 1 ㅇ, VIII. 7, 1956, Mt. Fukuchi, K. Sanada leg. (through Mr. Y. Takakura).

* The left basal angle is abnormally provided with two setae in the single specimen.

$\dagger$ The length of the elytra was measured from the shoulder to the apex of the elytra in parallel with the suture. 